\title{
THE EFFECTS OF RISK IN BANK GOVERNANCE - CREDINS BANK
}

CASE

\author{
Ejona Duçi ${ }^{191}$ \\ Elfrida Taraku ${ }^{192}$ \\ Enida Istrefi ${ }^{193}$
}

https://doi.org/10.31410/itema.2018.482

\begin{abstract}
The focus of this paper is the exposure of banks to various risks, how they affect the bank's benefits, to what extent, what are the results, what are the theoretically said, and what are the risks to which the banks "scared" the most.

Based on numerous studies carried out by different authors, the risks to which a bank is exposed are classified in macroeconomic risks and in specific risks that arise from bank activity itself.

In this study, we have focused on the three main risks that a bank faces most, namely the interest rate risk, exchange rate risk and credit risk. We have taken into consideration respectively the spread of the interest rate on loans with the deposit interest rate, the euro exchange rate, the dollar exchange rate and the ratio of bad debt provision to total loans to individuals.

For further analysis of these risks and for measuring their impact on a bank, it is reasonable to assume that a bank's profitability, as a benchmark for bank performance, bank shareholder returns, and a an important indicator of the effect of banking activity on a country's economy. On the basis of the linear regression built with the help of the E-views were answered questions raised and on the basis of regression coefficients we have received an answer regarding the extent of the impact of each of the above-mentioned risks in the bank's ROE, Credins Bank.
\end{abstract}

Keywords: exposure to risk, interest rate risk, exchange rate risk, credit risk, bank.

\section{Introduction}

$\mathrm{T}$ he banking system in Albania plays a key role in the development of the economy and the country. It is the main channel of funds from the subsidiaries to the deficit entities, which it performs through the provision of banking products, respectively deposits and loans. Because of the importance that the banking system has in our country, the study and treatment of the risks to which this system is exposed is an issue that deserves special care and treatment.

The main focus is exactly the banks' exposure to different risks, as these risks affect the bank's benefits, to what extent these risks are affected, and whether the results match theoretically and what is the risk to which banks are "scared". For the study of this link we will concentrate on the impact these risks have on bank ROE as an important indicator of the benefits and performance of banks as a whole. For the realization of this study, as an example bank is taken Credins Bank and we will use a linear regression as a suitable model to identify the link between different variables.

\footnotetext{
${ }^{191}$ University “Aleksandër Moisiu” of Durrës, kampusi i ri universitar, Spitallë, Durres; Albania

192 University “Aleksandër Moisiu” of Durrës , kampusi i ri universitar, Spitallë, Durres; Albania

${ }^{193}$ University “Aleksandër Moisiu” of Durrës, kampusi i ri universitar, Spitallë, Durres; Albania
} 
The E-Views program and the Excel program were used for model building. For the construction of the model, the annual reports published by Credins Bank have been taken into account since 2003 (the year of the establishment of the Credins bank) and until 2015, statistics published by the BoA regarding deposit interest rates and of credits over the years and statistics published by OPEN DATA regarding exchange rates.

Based on the correlation coefficients, the factors are ranked by importance in the descending order in such a way: the ratio of bad debt, the interest rate differential of the deposit interest rate and the exchange rate at euro. The most important factor, is the bad debt ratio, which we have calculated as the ratio of provisions for lost loans to total loans granted to customers, which means The higher the ratio, the greater will be the negative impact it has on the bank's profitability, namely the Return on Equity.

\section{Objective of the study}

In this context, the main objective of the study is to identify the risks that affect the bank's profitability. Other specific objectives include:

1. Realizing an empirical analysis at the level of a second tier bank

2. Through empirical analysis we find the extent of the impact of different risks on the bank's profitability in the study

3. To draw conclusions and make valid recommendations regarding the bank being analyzed.

\section{Research question}

To achieve the objectives set out above, we have raised some questions that will help us in obtaining the answers we seek. The research questions raised are:

1. What are the risks to which banks are exposed?

2. How do these risks affect the bank's profitability in the study?

3. How big is the impact on profitability?

\section{The hypotheses of the study}

In accordance with the required objectives and research questions, hypotheses are also formulated that will assist us in the realization of our study and will be presented in more detail in the third chapter of this paper. The study's hypotheses relate to theories related to bank profitability that have been developed over the years by banking sector researchers and other empirical studies related to profitability in banks. The three hypotheses formulated and assisted in drawing conclusions are:

H01: The difference between the credit interest rate and the deposit interest rate does not have a direct impact on the profitability of the bank

Ha1: The difference between the interest rate on loans and the deposit interest rate has a direct impact on the profitability of the bank

H02: Bad debt does not have a direct impact on the bank's profitability

Ha2: The bad debt has a direct impact on the bank's profitability

H03: The Euro Exchange Rate does not have a direct impact on the bank's profitability

Ha3: The Euro Exchange Rate has a direct impact on the bank's profitability 


\section{Model and definition of variables}

To carry out the study, we will use a linear regression as a suitable model to identify the link between different variables.

In the regression in question, the subordinated variable (Y) is the return on equity (ROE), calculated as the ratio of net profit (profit after tax) to the total share capital. Regarding the independent variables, we suggest that as macroeconomic factors are selected:

- Spread (the average interest rate spread of the loans with the average interest rate on deposits);

- Exchange rates in euro, As a banking factor it was selected;

- The ratio of provisions for bad debt to total loans.

Regarding the variables, return on equity (ROE) has been selected as a floating variable, as in a bank, as in any other business, the major exposed entities are its shareholders and the ROE best reflects the fluctuations in the benefits shareholders depending on independent variables.

Since banks are businesses whose main earnings are credit or lending interests, and one of the banks' expenses are deposits interests, it is precisely selected as one of the independent variables the average interest rate spread of the loans at the rate of the average deposit interest (spreadin). The expansion of the markets, the globalization of the economy, has made banks and other businesses expanding their activity in other countries, thus exposing them to exchange rate risk. Given the fact that the Credins bank, the largest number of foreign currency transactions in the euro and the dollar, these two courses for independent variables are exactly selected.

Another problem faced by banks is the exposure to credit repatriation, which has to do with the risk of non-payment of liabilities by borrowers. For this reason, the bad debt ratio with the total of loans is another independent variable that has been taken into consideration. The period of the work study includes a relatively long period that goes from 2003 to 2015 .

\section{Independent variables.}

The performance of interest rates on loans and deposits. We emphasize that the average interest rates on loans and deposit interest (spread) were taken into account. As we can see from the graph, the difference between the two average rates is basically the same, except for 2003 and 2004. Low borrowing rates in 2003 may have been used by the bank as a strategy to attract customers, but their big change is noticeable immediately after one year. Further, there is a decrease in the credit rate, which may have come as a result of competition, in parallel with the growth of the deposit rate until 2009, after which they have been increasingly falling, the lowest level of which was reached in 2015. The effect of interest rates on bank profits was reviewed by Samuelson (1945). It has been shown that in general terms, banks' profits tend to increase if interest rates are on the rise. Short (1979) also found a positive relationship between nominal interest rates and profitability indicators. 
Figure 1: The performance of the interest rate difference of interest rates on deposits, 20032018

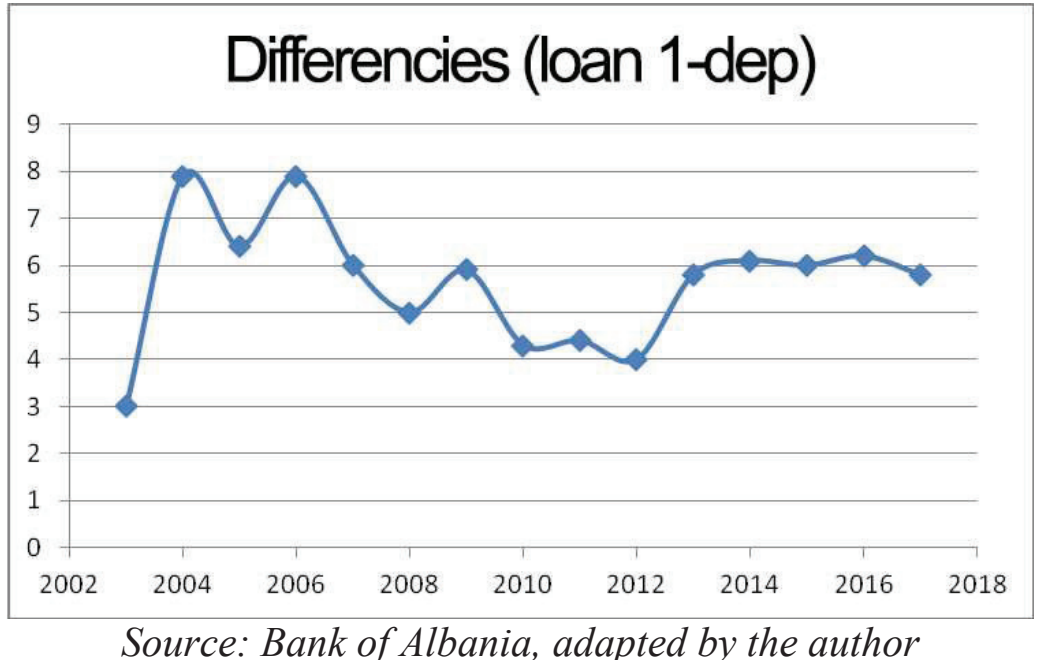

Euro exchange rate performance. Based on figure no. 2, we see that around 2007-2008, the Euro has depreciated against the lek, a consequence of the 2008 global crisis. Further, the Euro has had a growing trend of appreciation compared to the lek, an increase that has come as a result of a series of factors that have affected the offer and demand for Euro. As such we mention: borrowing in Euros for the purchase of immovable property by individuals; visa liberalization has increased the demand of individuals to spend holidays or purchasing products abroad, mainly in European countries; Visa liberalization has increased the number of individuals visiting migrant relatives by reducing the number of returning migrants to Albania, which reduces the Euro market offer during the summer months compared to previous years; the political situation in Albania and the various events that have taken place, have removed foreign investors, which reduces the demand for domestic currency. To conclude whether the euro exchange rate has a positive or negative impact on the bank's profitability, we must also analyze the loan-deposit ratio for the bank in question. Under the conditions when the percentage occupied by deposits in the total of the liability is greater than the percentage of loans in the total assets, then it is clear that the bank has more deposits in euro than loans to customers; therefore the impact will be negative, as the bank will have higher spending in the euro; conversely, if the bank would have more credit in euro's than the deposit. Another factor to mention is the fact that the euro exchange rate may have a negative impact even in cases where euro-denominated loans were at fixed rates, thus being more exposed to exchange rate volatility.

Figure 2: Euro exchange rate performance

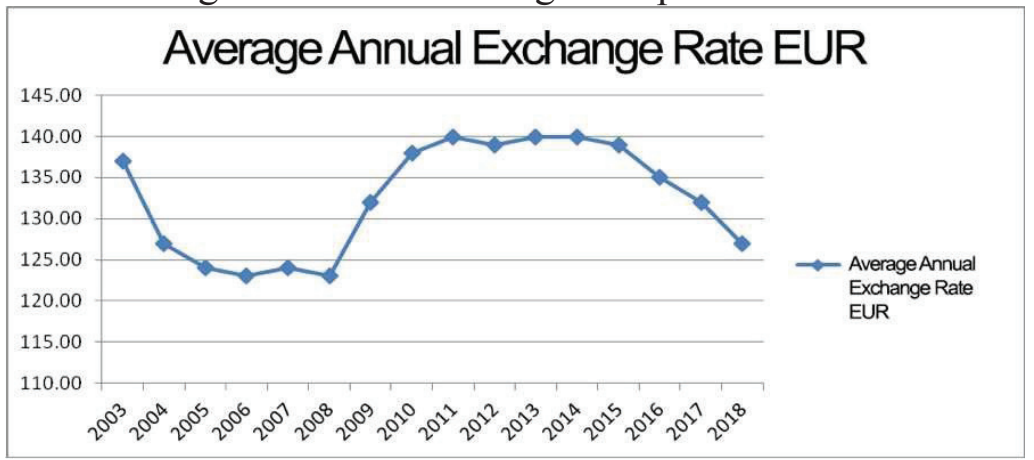

Source: Bank of Albania, adapted by the author 
Figure 3: The bad debt performance

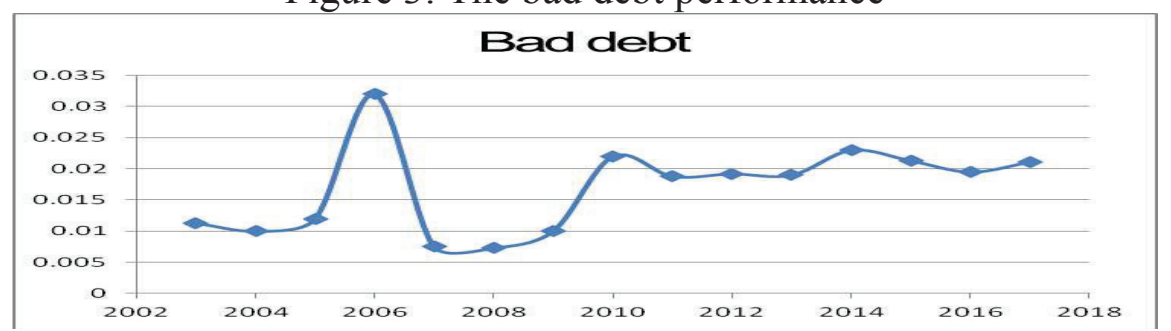

Source: Financial Reports Credins Bank, adapted by the author

The bad debt performance. For the treatment of bad debt, the ratio of provisions to total loans granted to customers was taken into account. "Provision for loan losses" is reported as a counter-calculation of the "Loan to Clients" account. This is an indicator that is expected to have a negative impact on the profitability of banks, and is therefore included in this study to measure the effect on profitability. The report in some way shows the level of risk to which the bank is exposed. As we see in the chart, in 2006, there has been an increase in the value of provisions for bad debt, an increase which may have come for several reasons, such as increasing the level of credit to individuals, reducing the credibility to clients and a possible increase in subordinated, doubtful and lost loans. After this fluctuation, it seems that this level is kept within a certain interval which does not exceed $2.2 \%$

\section{Dependent variables}

Return on Equity (ROE). As a dependent variable in this study, ROE was used as an indicator of profitability in the regression analysis because ROE has been widely used in previous studies as a profitability index and information measure for which it was not only easier to "provide by the annual reports of the banks under review but also because it remains one of the best indicators to measure the profitability of Albanian banks that has direct connection to the earned income in relation to the invested capital". So ROE, which is measured as a net equity income ratio, is widely used to measure banks' profitability in the banking system. An increase in ROE is a positive phenomenon; however, the factors that may have caused it may be different and may affect the interpretation of the results. However, referring to this indicator over the years in the case of system banks, ROE changes in recent years have mainly come from fluctuations in profit margins and risk levels. An initial negative ROE indicates the negative result the bank had in the opening year, but the result seems to have rebounded quickly. We also add that the financial crisis has given its effects two or three years later. How this indicator is influenced by the aforementioned variables will be studied in the following.

Figure 4: Return on Equity (ROE)

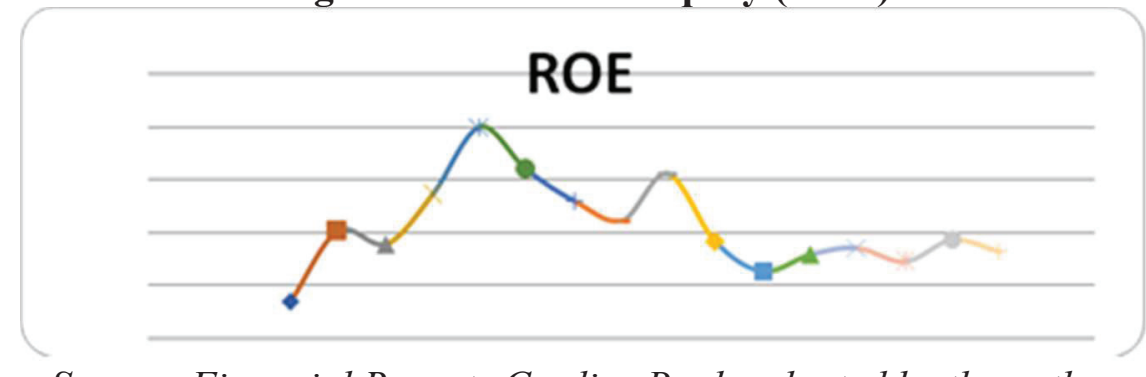

Source: Financial Reports Credins Bank, adapted by the author 


\subsection{Raise statistical model hypotheses}

The most important role building hypothesis is that it guides the direction of the study towards a problem in the research study.

The basic hypothesis that supports the main research question is presented as follows:

- H0: There is no statistically significant link between the variables studied with the bank's profitability in the study. This is the main hypothesis, the rejection of which will lead to the acceptance of the alternative hypothesis along with its 4 sub-hypotheses.

- Ha: If At least one of the variables taken in the study $(\beta 1, \beta 2, \beta 3)$ has an impact directly and statistically significant in the bank's profitability.

To test the relationship between ROE and Spread (Ikredi - Idep), the following hypotheses have been raised:

- H01: $\beta 1=0$ (The difference between the interest rate on loans and the interest rate on deposits does not have a direct impact on the bank's profitability)

- Ha1: $\beta 1$ \# 0 (The difference between the interest rate on loans and the deposit interest rate has a direct impact on the bank's profitability)

To test the relationship between ROE and Bad Debt (Loan Provision for Loans to Individual Clients), the following hypotheses have been raised:

* H02: $\beta 2=0$ (Bad debt does not have direct impact on bank profitability)

* Ha2: $\beta 2$ \# 0 (Bad debt has a direct impact on bank profitability)

To test the relationship between the ROE and the Euro exchange rate, hypotheses have been raised the following:

H03: $\beta 3=0$ (The Euro Exchange Rate does not have a direct impact on the bank's profitability)

* Ha3: $\beta 3$ \# 0 (The Euro Exchange Rate has a direct impact on the bank's profitability)

\subsubsection{Processing and testing of statistical data}

As mentioned at the beginning of this issue, a linear model was chosen for data analysis and hypothesis testing.

For the construction of the model, the annual reports published by Credins Bank have been taken into account, from 2005 to 2015, statistics published by the BoA regarding deposit and loan interest rates over the years, and published statistics from OPEN DATA regarding exchange rates. The E-Views program and the Excel program were used for model building.

For the evaluation of these data a statistical model based on the MKV method (the least square method) was used with a confidence level of $\mathrm{p}=95 \%$ or a $5 \%$ significance level. To draw conclusions on whether the factors under consideration impact on the bank's profitability or not, and if so, how it will affect, it will be based on the interpretation of correlation coefficients (coefficients $\beta$ ) and other coefficients such as of definability, the adjusted coefficient of determination etc. The study was based on 13 observations (13 years during which the study is being conducted), 5 variables in the model and 4 explanatory variables.

The table below summarizes the statistical data about the variables taken in the study for Credins Bank. 
Table 1: Descriptive statistics for variables taken in the study, 2005 - 2017

\begin{tabular}{|l|l|l|l|l|l|}
\hline Variables & $\begin{array}{l}\text { No. } \\
\text { observations }\end{array}$ & Min & Max & Average & $\begin{array}{l}\text { Stand. } \\
\text { Deviation }\end{array}$ \\
\hline ROE & 13 & -0.04103 & 0.295462 & 0.117722 & 0.092091 \\
\hline Spread & 13 & 0.029 & 0.077 & 0.056 & 0.013584 \\
\hline BD & 13 & 0.004938 & 0.032322 & 0.015438 & 0.007705 \\
\hline ERE & 13 & 122.8 & 140.3301 & 132.928 & 7.514222 \\
\hline
\end{tabular}

Source: Author's calculations

Assessing the data from the table above we draw the following conclusions about the variables taken in the study for the period 2005-2017:

First: Credins Bank has an average ROE of $11.77 \%$ and a standard deviation equal to $9.20 \%$. The smallest ROE value the bank has received in the year of its establishment. After this year, ROE levels have been generally good.

Second: The average spread (credit interest rate and deposit interest rate) is $5.6 \%$, while the deviation from the average is $1.35 \%$.

Thirdly, the ratio of provisions to loans is on average $1.54 \%$ and the deviation from the average is $0.77 \%$.

Finally: The euro exchange rate over these years has captured an average value equal to 140.33 and a standard deviation equal to 7.51. Normally, the euro appreciation against the lek or vice versa is influenced by the various factors we have mentioned above.

\subsubsection{The results of the economic model and their interpretation}

The econometric model obtained from the analysis of the collected data is presented as follows:

$\mathrm{ROE}=0.7117+0.003236 * \mathrm{SP}-0.3592 * \mathrm{BD}+0.000168 * \mathrm{ERE}(1)$

Before proceeding with the analysis of each of the variables, we must answer the main hypothesis we have risen, which is related to the global significance of the model, and then examine the statistical significance of each of the variables.

Regarding the statistical significance of the variables, we will start from the student's test ( $t$ statistic or observed) and the probabilities for each variable, identified in the E-Views program. Based on the following table (No. 2), we draw the following data:

Table 2: Table of data

\begin{tabular}{|c|c|}
\hline VARIABLES & PROB. FROM E-VIEWS \\
\hline SPREAD-I & 0.0792 \\
\hline $\begin{array}{c}\text { REPORT PROCEEDINGS TO } \\
\text { CREDIT }\end{array}$ & 0.0165 \\
\hline EXCHANGE RATE IN EURO & 0.0715 \\
\hline
\end{tabular}


to conclude whether independent variables are statistically significant or not comparable, or more critically observed, or the probabilities above with the 5\% significance level. As we see, two of the variables, respectively the spread and the euro exchange rate, are statistically unimportant for the level of 5\%, but are statistically significant for the level of $10 \%$, while the other two variables result statistically significant.

Based on the correlation coefficients, the factors are ranked by importance in the descending order in such a way: the ratio of bad debt, the interest rate differential of the deposit interest rate and the exchange rate at euro. Of course, the most important factor, among the factors taken into consideration, as it was expected, is the bad debt ratio, which we have calculated as the ratio of provisions for lost loans to total loans granted to customers, which means: The higher the ratio, the greater will be the negative impact it has on the bank's profitability, namely the Return on Equity.

- Ho No statistically relevant link between the variables taken into consideration with the bank's profitability in the study spelled down $\mathrm{HO}$

- Ha - If At least one of the variables taken in the study $(\beta 1, \beta 2, \beta 3)$ has an impact directly and statistically significant in the profitability of banks. ----Accepted $\mathrm{Ha}$

To test the global importance of the system of course, we refer to Fisher's values.

The analysis shows that Fisher's value of 4 and 8 degrees of freedom $(\alpha=0.05)$ is 4.439502 , greater than the critical Fisher value of 3.837853, which indicates that the model is statistically significant; independent variables in the model are mutually statistically different from zero. So, with this result since Fisher's current value is higher than the critical one, we have enough data to reject Ho (zero hypothesis) and to accept the hypothesis Ha (alternative hypothesis) that there exists at least one variable with different coefficients from zero that affects the variable taken in the study.

Based on the results presented in table no. 3, we say:

Since R2 (Determination Coefficient) marks the figure 0.689417 or more simply

$68.94 \%$ shows that the variables we have taken in the study explain in the regression model at $69 \%$ dependent variable. Naturally, this figure is satisfactory, because many other internal and external factors that could affect the profitability of the bank were not taken into account in order to be realistic in the study. So, we conclude that this value indicates a relatively high explanation of the variables we have taken in our study that are good representatives.

Whereas the adjusted R2 marks the value of 0.584125 which is, of course, a little smaller than the probability coefficient due to the number of variables taken in the study. These determinability coefficients indicate that there are still variables that are not included in the model that affect the bank's profitability and may be macroeconomic factors but also other internal indicators such as liquidity or other financial factors.

Normal distribution of waste. Another important element for an econometric model is the fulfillment of some key assumptions about the model. The main assumption is that the wastes have normal distribution. Through the E-Views program, we conclude that waste tends to have normal distribution, but there are also deviations. This comes as a result of the small number of surveys, which means that in the conditions when the regression would be built on the basis of 
a larger number of observations, then the results would be more accurate and closer to reality. In other words, the more we increase the number of elections, the more results will converge towards the real value of the population.

Autocorrelation. Based on the value of the Durbin Watson index, resulting in 1.655153 in our model, i.e. close to 2 , we say that our model built to test the link between profitability and specific banking and macroeconomic factors does not suffer from autocorrelation. We say that we would have to deal with the problem of autocorrelation when the remnants of the model would not be correlated. In such cases, to continue with it, it is necessary to eliminate selfreliance.

Multicollinearity. We say that we would be in multicollineary terms, so the variables would have linear links between them, if the correlation coefficient would be too high and the coefficients of the variables would be statistically insignificant. We are not in such conditions, so our model does not suffer from multicellularity.

The following table presents the regression output, in which we are also focused on giving some of the above answers.

Let us draw some conclusions about the interpretation of regression coefficients that have an impact on the dependent variable that measures the bank's profitability and performance, that is ROE.

Dependent Variable: ROE Method: Least Squares Date: 15/04/18 Time: 19:51 Sample: 113 Included observations: 13

$$
\mathrm{ROE}=\beta(0)+\beta(1) * \mathrm{~S}+\beta(2) * \mathrm{BD}+\beta(3) * \mathrm{ERE}
$$

Table 3: Study results

\begin{tabular}{|l|r|r|r|r|}
\hline & Coefficient & Std. Error & t-Statistic Prob. & \\
\hline \hline$\beta(0)$ & $\mathbf{0 . 7 1 1 7 1 3}$ & 0.571519 & 1.245301 & 0.2483 \\
\hline$\beta(1)$ & $\mathbf{0 . 0 0 3 2 3 7}$ & 0.092091 & 1.156925 & 0.0792 \\
\hline$\beta(2)$ & $\mathbf{- 0 . 3 5 9 2 3 7}$ & 0.013584 & -3.108229 & 0.0165 \\
\hline$\beta(3)$ & $\mathbf{0 . 0 0 0 1 6 9}$ & 0.007705 & 1.036902 & 0.0715 \\
\hline R-squared & $\mathbf{0 . 6 8 9 4 1 7}$ & Mean dependent var & & 0.117722 \\
\hline Adjusted R-squared & $\mathbf{0 . 5 8 4 1 2 5}$ & S.D. dependent var & & 0.092091 \\
\hline S.E. of regression & 0.072271 & Akaike info criterion & & -2.133058 \\
\hline Sum squared resid & 0.041785 & Schëarz criterion & & -1.915770 \\
\hline Log likelihood & 18.86488 & Hannan-Quinn criter. & & -2.177721 \\
\hline F-statistic & $\mathbf{4 . 4 3 9 5 0 2}$ & Durbin-Ëatson stat & & $\mathbf{1 . 6 5 5 1 5 3}$ \\
\hline Prob (F-statistic) & 0.095421 & & & \\
\hline
\end{tabular}

Source: Author's calculations

We start from what we have termed as X1, respectively the interest rate spread of the loans with the interest rate on deposits. What we are told by the coefficient $\beta 1$ is that for any change with a unit of this indicator, return on equity will increase by $0.3 \%$ if other variables are kept constant. In fact, the impact that interest rates have on bank profitability and performance is even higher, since banking activity itself is such that the largest part of the income generates 
from the interest on the loans granted, but given that we have taken the marginal interest, its effect becomes more relaxed, as logically we are studying the impact that this difference results in, so we are studying the impact of a smaller value. For level of $10 \%$ significance, we say that the zero hypothesis is rejected. In relation to the hypotheses raised for X1:

* H01: $\beta 1=0$ (The difference between the loan interest rate and the deposit interest rate does not have a direct impact on the bank's profitability) - Disown HO

* Hal: $\beta 1$ \# 0 (The difference between the interest rate on loans and the deposit interest rate has a direct impact on the bank's profitability) - Accepted Ha

A very important variable is also the bad debt ratio, which we have mentioned as a ratio of provisions for lost loans to the total of loans granted to customers. It was also expected that this report would have a significant and direct impact on the bank's profitability. What banks aim consistently is to reduce the level of lost loans or defined sub-criteria, taking into account the fact that the latter's impact on bank benefits is huge. Thus, it results from our model, for any change with a bad debt ratio unit, return on equity decreases by $35.9 \%$, under conditions where other variables are kept unchanged. In addition to the relatively large impact on return on equity, through this coefficient, we conclude that the bank is highly exposed to credit risk, i.e. the risk of partial or total loss of credit to customers, a risk which, if it occurs, would cause the bank considerable losses. For the 5\% level, we say that the zero hypothesis is rejected. Regarding the hypotheses raised for this variable, we say that:

* H02: $\beta 2=0$ (Bad debt does not have direct impact on bank profitability) Disown H0

* Ha2: $\beta 2$ \# 0 (Bad debt has a direct impact on bank profitability) -- Accepted Ha

The euro exchange rate appears to have a positive impact on the bank's profitability, albeit small. That is to say, for each one unit of exchange in the euro exchange rate, the return on the bank's equity will increase by $0.0169 \%$, under conditions where other factors are kept unchanged. For the level of importance 10\%, the zero hypothesis have been discarded. Regarding the hypotheses raised for this variable we say that:

* H03: $\beta 3=0$ (Euro exchange rate does not have direct impact on bank profitability) Drop down $\mathrm{HO}$

* Ha3: $\beta 3$ \# 0 (Euro exchange rate has a direct impact on bank profitability) Accepted Ha

Table 4: Summary of study results

\begin{tabular}{|c|c|c|}
\hline HYPOTHESIS & DECISION & $I M P A C T$ \\
\hline $\begin{array}{l}\text { SPREAD HAS IMPROVED IMPACT BENEFIT ON } \\
\text { THE BENEFITABILITY OF THE BANK }\end{array}$ & $\begin{array}{c}\text { TO BE } \\
A C C E P T E D \\
(10 \%)\end{array}$ & POSITIVE \\
\hline 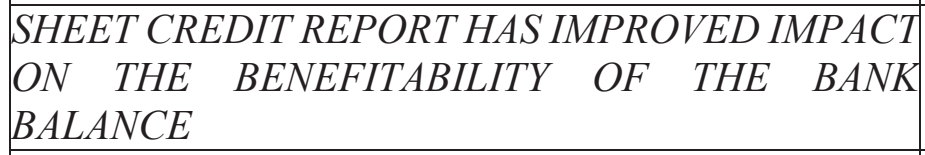 & $\begin{array}{c}\text { TO BE } \\
A C C E P T E D \\
(5 \%)\end{array}$ & NEGATIVE \\
\hline $\begin{array}{l}\text { EXCHANGE RATE IN EURO HAS IMPROVED } \\
\text { IMPACT ON THE BENEFITABILITY OF THE BANK }\end{array}$ & $\begin{array}{c}\text { TO BE } \\
\text { ACCEPTED } \\
(10 \%)\end{array}$ & POSITIVE \\
\hline
\end{tabular}

Source: Author's calculations 


\section{CONCLUSIONS}

The objective of the subject matter was to identify the risks to which a bank is exposed and to measure their impact on the bank. To show the sign and the extent of the impact of some risks on the example bank, we constructed a linear regression with three independent variables and a dependent variable, i.e. the example bank ROE, Credins Bank. The ROE was selected as a dependent variable for some key reasons such as:

1. An important indicator of the benefits and performance of banks as a whole.

2. An important indicator not only because of the information it provides about the health of the economy every year, but also because profits are a key determinant of growth and employment in the medium term.

Regarding the risks faced by the Albanian banking sector, the Bank of Albania evaluates the following:

1. Credit risk has experienced an increase during the first semester of 2016. The value of non-performing loans increased by $11.7 \%$ and the ratio of non-performing loans to the banking sector has climbed to $20 \%$, compared to $18.2 \%$ at the end of 2015 . The main contribution to this growth of non-performing loans has been provided by credit to businesses, foreign currency credit and medium-term loans. The growth of nonperforming loans was accompanied by a slight reduction of their coverage with reserve funds and equity, although these indicators remained close to the levels of the previous year. For the first quarter of 2018, the level of non-performing loans remains higher than the end of 2017 , when it reached $13.2 \%$ of total loans, with a significant drop of 5 percentage points compared to December 2016 when were $18 \%$. This was the lowest level of problematic loans since December 2010.

2. The liquidity risk in banking activity is low. The low value of the ratio of loans to deposits, the continuation of deposit growth, and the high presence of liquid assets on the minimum requirements of the regulatory framework, indicate a very good situation of the banking sector's liquidity situation.

3. The banking sector is exposed to market risk (including exchange rate risk and interest rate risk), despite the decrease in the size of exposure during the period. The direct risk of exchange rate on banking activity is limited, as the assets and liabilities in foreign currency are approximate, while the provision for credit risk provisions and the whole (for other types of assets) exhibit substantial growth compared to the previous year, respectively by $15.8 \%$ and $30.4 \%$.

According to the study conducted, based on the built econometric model and the interpretation of the respective coefficients, we have come to the conclusion that:

1. Based on the correlation coefficients, the factors are ranked by importance in the descending order in such a way: the ratio of bad debt, the interest rate differential of the deposit interest rate and the rate of interest rate exchange rate in euro's. Of course, the most important factor, among the factors taken into consideration, as it was expected, is the bad debt ratio, which we have calculated as the ratio of provisions for lost loans to total loans granted to customers, which means: The higher the ratio, the greater will be the negative impact it has on the bank's profitability, i.e. the return on equity.

2. For any change with a spread unit, return on equity will increase by $0.3 \%$ if other variables are kept constant.

3. What banks are aiming consistently is to reduce the level of lost loans or defined subcriteria, taking into account the fact that the latter's impact on bank benefits is huge. Thus, it results from our model, for any change with a bad debt ratio unit, return on 
equity decreases by $35.9 \%$, under conditions where other variables are kept unchanged. In addition to the relatively large impact on return on equity, through this coefficient we conclude that the bank is very exposed to credit risk, i.e. to the risk of non-payment of part or all of the loans granted to the client, a risk which would, if present, cause the bank considerable loss.

4. The exchange rate in euro results to have a positive impact on the bank's profitability, albeit small. That is to say, for each one unit of exchange in the euro exchange rate, the return on the bank's equity will increase by $0.0169 \%$, under conditions where other factors are kept unchanged.

\section{RECOMMENDATIONS}

Based on the conclusions drawn and the research conducted, below we will make some recommendations:

1. As we can see from the model, the internal risks to which the bank is exposed have more impact on bank profitability than macroeconomic factors. However, in order to preserve high or acceptable levels of ROE, a bank should, in drafting strategies, have a strong record in managing specific risks, primarily credit risk, but also considering the macroeconomic environment and the risks that arise from it.

2. Improving such indicators as credit risk, other indicators related to the internal and macroeconomic environment, will have a positive impact on improving ROE, i.e. the bank's profitability.

3. Carefully and comprehensively study the borrower's clients, in order to avoid or reduce as much as possible the problems that may arise with the partial or full repayment of the loan, with increased vigilance.

4. Exposure of the banking sector to unfavorable exchange rate movements should be regularly assessed and followed carefully.

5. Bank capitalization should be encouraged so that banking performance can grow. A well-capitalized banking system will provide financial stability and will make the industry more flexible to external shocks and risks. This is because well-capitalized banks have lower financial risk and are therefore more likely to survive financial crises.

6. Finally, given that only three variables that affect the bank's profitability are taken into account in the study, it is recommended that future studies take into account more risks or factors that affect the bank's profitability to achieve more accurate results.

\section{REFERENCES}

[1] Ali, S. NDIKIMI I FAKTORËVE MAKROEKONOMIKE DHE BANKARE NE NIVELIN E KREDIVE ME PROBLEME NE SISTEMIN BANKAR SHQIPTAR, 2002.

[2] Banks risk exposure, June 2015

[3] EFFECTS OF BANKING SECTORAL FACTORS ON THE PROFITABILITY OF COMMERCIAL BANKS IN KENYA, Tobias Olweny, Themba Mamba Shipho, July 2011.

[4] https://www.researchgate.net/publication/228251895_The_Causal_Relationship_betw

een_Bank_Capital_and_Profitability .

[5] http://www.na-businesspress.com/JABE/CaseyKM_Web16_2_.pdf. (n.d.).

[6] https://file.scirp.org/pdf/JSS_2014082610400602.pdf. (n.d.).

[7] https://myWeb.rollins.edu/tlairson/seminar/bankprofits.pdf. (n.d.).

[8] https://www.bankofalbania.org/ëeb/DEKLARATEEBANKES_SE_SHQIPERISE_77 53_1.php?kc=0,5,0,0,0. (n.d.). 
[9] https://www.bankacredins.com/index.php/rreth-nesh/historiku/

[10] Orfea, D. Drejtimi i riskut. December 2016

[11] Principles for the Management of Credit Risk, September 2000.

[12] Raporti vjetor i mbikëqyrjes, viti 2016. (n.d.). Banka e Shqipërisë, 2016.

[13] Risks and Risk Management in the Banking Sector. (n.d.), may 2018.

[14] Raporti vjetor 2016, Credins Bank.2016.

[15] Sustainable Risk Management in the Banking Sector, Ivo Županović, March 2014.

[16] (A STUDY ON THE RETURN ON EQUITY FOR THE ROMANIAN INDUSTRIAL COMPANIES)(Garcia \& Guerrei., June 2017. 